\title{
Review
}

\section{Why do anti-inflammatory therapies fail to improve insulin sensitivity?}

\author{
Zhan-guo GAO, Jian-ping YE* \\ Antioxidant and Gene Regulation Lab, Pennington Biomedical Research Center, Louisiana State University System, Baton Rouge, LA \\ 70808 , USA
}

\begin{abstract}
Chronic inflammation occurs in obese conditions in both humans and animals. It also contributes to the pathogenesis of type 2 diabetes (T2D) through insulin resistance, a status in which the body loses its ability to respond to insulin. Inflammation impairs insulin signaling through the functional inhibition of IRS-1 and PPARy. Insulin sensitizers (such as rosiglitazone and pioglitazone) inhibit inflammation while improving insulin sensitivity. Therefore, anti-inflammatory agents have been suggested as a treatment strategy for insulin resistance. This strategy has been tested in laboratory studies and clinical trials for more than 10 years; however, no significant progress has been made in any of the model systems. This status has led us to re-evaluate the biological significance of chronic inflammation in obesity. Recent studies have consistently asserted that obesity-associated inflammation helps to maintain insulin sensitivity. Inflammation stimulates local adipose tissue remodeling and promotes systemic energy expenditure. We propose that these beneficial activities of inflammation provide an underlying mechanism for the failure of anti-inflammatory therapy in the treatment of insulin resistance. Current literature will be reviewed in this article to present evidence that supports this viewpoint.
\end{abstract}

Keywords: inflammation; insulin resistance; type 2 diabetes; insulin sensitizer; obesity

Acta Pharmacologica Sinica (2012) 33: 182-188; doi: 10.1038/aps.2011.131; published online 31 Oct 2011

\section{Introduction}

For about two decades, it has been known that inflammation contributes to obesity-associated insulin resistance. Inflammatory cytokines (eg, TNF-alpha, IL-1, and IL-6) have been shown to induce insulin resistance in multiple organs (fat, muscle and liver). TNF-a elevation was found in adipose tissue of obese mice in $1993^{[1]}$. That study provided the first evidence of the role of chronic inflammation during obesity and its association with insulin resistance in an animal model. Macrophages in adipose tissue are the major source of inflammatory cytokines in obesity ${ }^{[2,3]}$. Recent studies from multiple groups, including ours, consistently suggest that adipose tissue hypoxia is a root of chronic inflammation in obesity ${ }^{[4]}$. Hypoxia is likely the result of a reduction in blood flow to adipose tissue, which is supported by some studies in humans and animals ${ }^{[5-7]}$.

In addition to adipose tissue hypoxia, metabolites of fatty acids and glucose, including diacylglyceride (DAG), ceramide, and reactive oxygen species, also contribute to the chronic inflammation in obesity. They activate the inflammatory response in several ways. They can directly interact with sig-

\footnotetext{
* To whom correspondence should be addressed.

E-mail yej@pbrc.edu

Received 2011-08-01 Accepted 2011-09-06
}

naling kinases (PKCs, JNKs, and IKKs) in cells ${ }^{[8]}$; the lipids can also signal through cell membrane receptors for lipids, such as TLR4, CD36, or GPR ${ }^{[8-13]}$. Fat or glucose oxygenation in the mitochondria can also generate reactive oxygen species (ROS), which can then induce activation of the inflammatory kinases (JNK and IKK) in the cytoplasm. The lipids also induce endoplasmic reticulum (ER) stress to activate JNK and IKK ${ }^{[14,15]}$. In obesity, these signaling pathways are activated as a result of the surplus calories and involved in the pathogenesis of chronic inflammation.

\section{Chronic inflammation and insulin resistance}

At the molecular level, inflammation induces insulin resistance by targeting IRS-1 and PPAR $\gamma$.

Inflammation and IRS-1 (insulin receptor substrate 1)

In cellular models of insulin resistance, the pro-inflammatory cytokine, TNF- $a$, is widely used to induce insulin resistance. The data from these cellular studies suggest that TNF- $\alpha$ is a major risk factor for insulin resistance in obesity and other chronic diseases ${ }^{[1,16,17]}$. TNF- $a$ inhibits insulin signaling by serine phosphorylation of IRS-1, which leads to the dissociation of IRS-1 from the insulin receptor and causes degradation of IRS-1 protein ${ }^{[17-19]}$. In the insulin signaling pathway, IRS-1 
undergoes tyrosine in response to insulin stimulation, which leads to activation of the insulin signaling pathway, downstream PI3K/Akt activation, and Glut4 translocation to the cell membrane for glucose uptake. TNF-a induces insulin resistance by IRS-1 serine phosphorylation through the activation of several serine kinases, including JNK ${ }^{[20,21]}$, IKK ${ }^{[22]}, \mathrm{ERK}^{[23-25]}$, $\mathrm{PKC}^{[26-28]}, \mathrm{Akt}^{[28,29]}, \mathrm{GSK}-3^{[30-32]}, \mathrm{IRAK}^{[33]}$, and $\mathrm{mTOR}^{[34,35]}$. In a recent study, we showed that IKK2 (IKK $\beta$ ) inhibits IRS-1 function through the activation of S6K, which directly phosphorylates IRS-1 at multiple sites (such as S312/307 and S270/265) in TNF-a-treated cells ${ }^{[22,36]}$. Serine phosphorylation induces IRS-1 degradation and serves as a negative feedback signal to impair insulin action ${ }^{[35]}$.

\section{Inflammation inhibits PPARy function}

The IKK $\beta / N F-\kappa B$ (nuclear factor kappa B) pathway is a dominant inflammatory signaling pathway. The pathway has been under active investigation in the obesity field after IKK $\beta$ was found to induce insulin resistance in obese mice ${ }^{[37]}$. The serine kinase IKK has three major isoforms, including IKKa (IKK1), IKK $\beta$ (IKK2), and IKK $\gamma$, which requires IKK $\beta$ for NF-KB activation $^{[38]}$. In obesity, IKK $\beta$ is activated by several intracellular signals, such as ROS, ER stress, DAG, and ceramide. IKK $\beta$ is also activated by extracellular stimuli, including TNF- $\alpha$, IL-1, fatty acids ${ }^{[11]}$ and hypoxia ${ }^{[39]}$. IKK $\beta$ induces NF-KB activation by phosphorylation of the Inhibitor of Kappa B alpha $(\mathrm{IKBa})^{[40]}$.

$\mathrm{NF}-\mathrm{KB}$ is a ubiquitous transcription factor that is formed by two subunits of the Rel family, which includes seven members, p65 (RelA), p50 (NF-kB1), c-Rel, RelB, p100, p105, p52 ${ }^{[41]}$. These members form a homodimer or heterodimer that regulates gene transcription. In most cases, NF- $\mathrm{kB}$ is a heterodimer of p65 and p50. P65 contains the transactivation domain and mediates the transcriptional activity of NF-kB. P50 inhibits the transcriptional activity of $\mathrm{p} 65^{[42]}$, and the NF- $\mathrm{kB}$ activity is enhanced in p50 knockout mice ${ }^{[43]}$. NF-kB inhibits PPARY function through the competition for transcriptional coactivators or the exchange of corepressors with PPAR $\gamma^{[44]}$. This process is responsible for inhibiting PPAR-target genes, such as CAP and IRS-2. Our study shows that IKK promotes the activity of HDAC3 in the nuclear corepressor complex. IKK induces nuclear translocation of HDAC3 from the cytoplasm. In the cytosol, HDAC3 associates with IKBa, and the degradation of IкBa promotes HDAC3 translocation into the nucleus. The PPARY inactivation leads to suppression of IRS-2 expression, a signaling molecule in insulin signaling pathways for Glut4 translocation.

\section{Free fatty acids and insulin resistance}

Elevated plasma free fatty acids (FFAs) induce insulin resistance in obese and diabetic subjects ${ }^{[45]}$. It was known as early as 1983 that lipid infusion caused insulin resistance ${ }^{[46,47]}$. To examine the mechanism by which FFAs induced insulin resistance in vivo, rats were tested in a hyperinsulinemic-euglycemic clamp after a 5-h infusion of lipids/heparin, which raises plasma FFA concentrations ${ }^{[47]}$. FFAs resulted in an approximate $35 \%$ reduction in insulin sensitivity, indicated by the glucose infusion rate $(P<0.05$ vs control), and a $25 \%$ reduction in glucose transport activity, as assessed by 2-[1,2- $\left.{ }^{3} \mathrm{H}\right]$ deoxyglucose uptake in vivo ( $P<0.05$ vs control). PKC $\theta$ is a major kinase involved in FFA-induced insulin resistance ${ }^{[48]}$. According to the Randle glucose-fatty acid cycle, the preferential oxidation of free fatty acids over glucose plays a major role in the pathogenesis of insulin sensitivity ${ }^{[49]}$. Local accumulation of fat metabolites, such as ceramides, diacylglycerol or acyl-CoA, inside skeletal muscle and liver may activate a serine kinase cascade, leading to defects in insulin signaling and glucose transport ${ }^{[50]}$.

\section{Inflammation and energy metabolism}

Inflammation is associated with increased energy expenditure in patients with chronic kidney disease ${ }^{[51]}$, cachexia ${ }^{[52]}$, inflammatory bowel disease ${ }^{[53]}$ and Crohn's disease ${ }^{[54]}$. NF-кB activity can promote energy expenditure, as supported by documents on energy expenditure in cachexia ${ }^{[55,56]}$ and infection. However, the role of NF-kB in energy expenditure was not tested in transgenic models. To this end, we have investigated energy metabolism in transgenic mice with elevated NF- $\mathrm{KB}$ activity. The transcriptional activity of NF- $\mathrm{kB}$ is enhanced either by over-expression of NF-kB p65 in the fat tissue, or inactivation of NF-kB p50 by global gene knockout ${ }^{[57,58]}$. In these two models, inflammatory cytokines (TNF-a and IL-6) were elevated in the blood, and energy expenditure was increased both during the day and at night ${ }^{[57,58]}$. Expression of TNF- $\alpha$ and IL-1 mRNA was increased in adipose tissue and macrophages. These cytokines are positively associated with energy expenditure in the body ${ }^{[56]}$. In transgenic mice with deficiencies in these cytokines or their receptors, energy accumulation is enhanced and energy expenditure is reduced. This positive energy balance has been reported in transgenic mice deficient in TNF- $\mathrm{a}^{[59]}$, IL- $1^{[60]}$, or IL-6 ${ }^{[61]}$.

The above literature suggests that energy accumulation induces chronic inflammation. Inflammation may promote energy expenditure in a feedback manner to counteract an energy surplus ${ }^{[62]}$. Inflammation may act in the peripheral organs/tissues, as well as in the central nervous system, to regulate energy balance. In the peripheral tissues, inflammation induces fat mobilization and oxidation to promote energy expenditure. In the central nervous system, inflammation can inhibit food intake and activate neurons for energy expenditure, while inhibition of inflammation leads to fat accumulation $^{[62]}$

\section{Anti-inflammation therapies for insulin resistance}

In clinical trials, high-dose salicylate was used to inhibit inflammation by targeting $\mathrm{IKK} / \mathrm{NF}-\mathrm{KB}^{[37,63-65]}$. Salicylate reduces blood glucose by inhibiting $\mathrm{IKK} / \mathrm{NF}-\mathrm{KB}$, as seen decades ago in patients with diabetes ${ }^{[64-66]}$. More studies demonstrated that high-doses of aspirin ( 7.0 g/d) improved multiple metabolic measures in patients with T2D, including substantial reductions in fasting and postprandial glucose, triglycerides and FFAs. These changes were associated with reduced hepatic glucose production and improvements in 
insulin-stimulated glucose disposal, assessed during hyperinsulinemic-euglycemic clamping ${ }^{[63-65,67]}$. Aspirin inhibits the activity of multiple kinases induced by TNF-a, such as JNK, IKK, Akt, and mTOR. It may enhance insulin sensitivity by protecting the IRS proteins from serine phosphorylation ${ }^{[68]}$. However, the therapeutic value of high-dose aspirin is limited by its side effects, including gastrointestinal irritation and high risk of bleeding.

Statins, a class of anti-inflammatory drugs, have been shown to downregulate the transcriptional activity of NF-kB, AP-1, and HIF- $1 \mathrm{a}^{[65,69]}$, with coordinated reductions in the expression of prothrombotic and inflammatory cytokines. Randomized clinical trials have demonstrated that statins reduces $\mathrm{CRP}$, multiple cytokines, and inflammatory markers in the body. Even with modest anti-inflammatory properties, statins do not appear to enhance insulin resistance or significantly improve glycemia ${ }^{[70]}$. A recent review published in JAMA suggests that statin therapy is associated with excess risk for diabetes mellitus. The researchers analyzed five earlier trials, involving 32752 patients, to test the effect of the drug dose. Those getting intensive treatment were 12 percent more likely to have diabetes ${ }^{[71]}$, which translates into a 20 percent increase in developing diabetes in the high-dose statin users compared to those who do not take the drugs.

Glucocorticoids are the most effective anti-inflammatory drugs used to treat inflammatory diseases. Dexamethasone is a potent synthetic member of the glucocorticoid class of steroid drugs. In a clinical study, the effect of dexamethasone on insulin-stimulated glucose disposal was investigated with a double-blind, placebo-controlled, cross-over trial comparing insulin sensitivity (measured by the euglycemic hyperinsulinemic clamp) in young healthy males allocated the placebo or 1 $\mathrm{mg}$ dexamethasone twice daily for $6 \mathrm{~d}$, each in random order. Six days of dexamethasone therapy was associated with a $30 \%$ decrease in insulin sensitivity ${ }^{[72,73]}$. This indicates that strong inhibition of inflammation may block the beneficial effects of inflammation on insulin sensitivity.

Interleukin-1 $\beta$ induces inflammation in islets of patients with type 2 diabetes $^{[74]}$. The interleukin-1-receptor antagonist, a naturally occurring competitive inhibitor of interleukin- $1^{[75]}$, protects human beta cells from glucose-induced functional impairment and apoptosis ${ }^{[76]}$. The expression of the interleukin-1-receptor antagonist is reduced in pancreatic islets of patients with type 2 diabetes mellitus. High glucose induces the production of interleukin-1 $\beta$ in human pancreatic beta cells, leading to impaired insulin secretion, decreased cell proliferation, and enhanced apoptosis. In this double-blind, parallel-group trial involving 70 patients with type 2 diabetes ${ }^{[74]}$, 34 patients were randomly assigned to receive $100 \mathrm{mg}$ of anakinra (a recombinant human interleukin-1-receptor antagonist) subcutaneously once daily for 13 weeks. In the control group, 36 patients received placebo. All patients underwent an oral glucose-tolerance test. At the end of the study, the two study groups exhibited no difference in insulin resistance, insulinregulated gene expression in skeletal muscle, serum adipokine levels, and the body-mass index. However, the therapy did improve blood glucose levels. The authors conclude that the improvement is from enhanced pancreatic $\beta$-cell function. This study indicates that inhibition of IL-1 $\beta$ improves glucose metabolism, independent of insulin sensitivity.

TNF- $\alpha$ expression is elevated in the adipose tissue of obese rodents and humans. In animal studies, administration of exogenous TNF- $\alpha$ induced insulin resistance, whereas neutralization of TNF- $\alpha$ improved insulin sensitivity. TNF- $\alpha$ knockout mice were used to examine the role of TNF- $a$ in obesityassociated insulin resistance ${ }^{[7]]}$. The $\mathrm{KO}$ mice were compared with WT mice in lean and obese (induced by gold-thioglucose [GTG]-injection) conditions at 13, 19, and 28 weeks of age. In the lean condition, the $\mathrm{KO}$ mice exhibited a $14 \%$ reduction in body weight at 28 weeks of age. The epididymal fat pad was decreased by $25 \%$ in weight, relative to those of the wild-type littermate controls. Fasting glucose was reduced slightly by $10 \%$, but the glucose response in an oral glucose tolerance test (OGTT) was not affected. In the obese condition, the body weight was identical between the KO and WT mice. Glucose levels were significantly increased in both groups during the OGTT. This indicates that the absence of TNF-a is not sufficient to protect mice from insulin resistance in obese conditions $^{[77]}$. Some animal studies ${ }^{[78]}$ and several clinical trials using TNF antagonism have thus far failed to improve insulin sensitivity ${ }^{[79-83]}$. These facts suggest that there are many unknowns in the relationship of obesity-associated inflammation and insulin resistance.

The role of IL-6 in the pathogenesis of obesity and insulin resistance is controversial. IL-6 knockout (KO) mice were compared with WT littermate mice in lean or obese conditions. IL-6 KO mice displayed obesity, hepatosteatosis, liver inflammation and insulin resistance when compared with the lean condition on a standard chow diet ${ }^{[84]}$. Overexpression of IL-6 was also used to test insulin resistance in mice. In the study, IL-6 overexpression was generated in skeletal muscle, and the IL-6 protein levels were increased in the circulation. The mice lost both body weight and body fat in response to IL-6 in this model, even though their food intake remained unchanged ${ }^{[85]}$. These observations suggest that IL-6 increases energy expenditure. In the IL-6 mice, insulin levels were elevated, and hypoglycemia was observed ${ }^{[85]}$. In another study, Sadagurski et al demonstrated that a high level of IL-6 in the circulation reduces obesity and improves metabolic homeostasis in vivo ${ }^{[86]}$.

The role of the anti-inflammatory cytokine IL-10 has been studied in the pathogenesis of obesity and insulin resistance ${ }^{[87]}$. IL-10 is a critical cytokine of M2 (type 2) macrophages. A recent study has identified the roles of M1 (pro-inflammatory) and M2 (anti-inflammatory) macrophages in the regulation of insulin sensitivity ${ }^{[88]}$. An increase in M2 macrophages and a decrease in M1 macrophages within the adipose tissue are associated with enhanced insulin sensitivity. In another study, the hematopoietic-cell-restricted deletion of IL-10 in mice was used to study the relationship between IL-10 and insulin resistance ${ }^{[89]}$. The mice were assessed for insulin sensitivity in an insulin tolerance test in lean (chow diet) and obese (high fat diet) conditions. The results show that deletion of IL-10 from 
the hematopoietic system does not have an effect on insulin resistance ${ }^{[89]}$. Other studies suggest that IL-10 cannot improve insulin sensitivity in diet-induced obese mice or humans $s^{[00,91]}$.

\section{New potential drug candidates for insulin resistance}

The antidiabetic drug thiazolidinedione (TZD) restores insulin action by activating PPAR $\gamma$, thus lowering the levels of FFAs in the blood. Activation of PPARY improves insulin sensitivity in rodents and humans through a combination of metabolic actions, including partitioning of lipid stores and regulating metabolic and inflammatory mediators, termed adipokines ${ }^{[92]}$. However, TZD-based medicines for insulin sensitization have many side effects: troglitazone (Rezulin) was associated with massive hepatic necrosis; rosiglitazone (Avandia) and muraglitazone, with increased cardiovascular events; and now, pioglitazone has been associated with bladder cancer ${ }^{[93]}$. These adverse events suggest that the thiazolidinedione-based drugs may not be safe in the long-run. It is necessary to discover a new class of drug to treat insulin resistance.

Recent studies indicate that histone deacetylase (HDAC) inhibitors may be a new class of drug candidates for insulin sensitization. HDACs are key enzymes in regulating gene expression. Protein acetylation is one type of epigenetic regulation of gene expression. Acetylation is controlled by histone acetyltransferases (HATs) and histone deacetylases (HDACs). Histone acetylation by HATs opens the chromatin structure to activate gene transcription, while histone deacetylases (HDACs) repress gene expression. HDACs are divided into three classes: class I HDACs $(1,2,3,8,11)$, class II HDACs $(4,5,6,7,9,10)^{[94]}$ and class III HDACs (SIRT1-7) ${ }^{[95]}$. Inhibition of histone deacetylase activity has been reported as a new approach to treat diabetes mellitus ${ }^{[96-98]}$. In our study, supplementation of histone deacetylase inhibitors, butyrate or Trichostatin A, prevented high-fat diet-induced obesity and improved insulin sensitivity in mice. HDAC inhibition promoted energy expenditure, and reduced blood glucose and triglyceride levels in mice ${ }^{[98]}$. HDAC inhibits insulin resistance on a molecular level by the following means: a) reducing the lipid toxicity ${ }^{[4,}$,99-102]; b) reducing chronic systemic inflammation $^{[103-108]}$; c) promoting beta-cell development, proliferation, differentiation and function ${ }^{[97]}$; and d) promoting energy expenditure $\mathrm{e}^{[98,109]}$. Based on their multiple beneficial effects, HDAC inhibitors may represent a novel drug in the treatment of insulin resistance. However, clinical trials are needed to test this concept.

\section{Conclusions}

Type 2 diabetes is one of the major diseases associated with obesity. It is known that obesity promotes type 2 diabetes through insulin resistance, a state in which bodies lose their responsiveness to insulin. Many studies confirm that inflammation and free fatty acids (FFAs) are major pathogenic factors for insulin resistance in obese conditions. The most effective therapy for insulin resistance is to reduce both FFA and inflammation. Diminishing inflammation by anti-inflammatory drugs does not significantly improve insulin sensitiv- ity in animal models or in clinical trials because inflammation is beneficial in regulating energy metabolism. Inhibiting this beneficial activity is likely to cause the failure of anti-inflammatory drugs in treating insulin resistance. Current literature consistently reports that fatty acids remain a therapeutic target in the treatment of insulin resistance. As an insulin sensitization-drug, TZD reduces both FFA and inflammation in the body. However, TZDs have many side effects such as obesity, heart attacks, and bladder cancer. HDAC inhibitors may be a new class of drug for treating insulin resistance by promoting energy expenditure and preventing obesity.

\section{Acknowledgements}

This work is partially supported by NIH grants DK068036 and DK085495 to Jian-ping YE and an NIH COBRE grant (2P20RR021945) and ADA grant (1-09-JF-17) to Zhan-guo GAO.

\section{References}

1 Hotamisligil GS, Shargill NS, Spiegelman BM. Adipose expression of tumor necrosis factor-alpha: direct role in obesity-linked insulin resistance. Science 1993; 259: 87-91.

2 Xu H, Barnes GT, Yang Q, Tan G, Yang D, Chou CJ, et al. Chronic inflammation in fat plays a crucial role in the development of obesityrelated insulin resistance. J Clin Invest 2003; 112: 1821-30.

3 Weisberg SP, McCann D, Desai M, Rosenbaum M, Leibel RL, Ferrante AW Jr. Obesity is associated with macrophage accumulation in adipose tissue. J Clin Invest 2003; 112: 1796-808.

4 Ye J, Gao Z, Yin J, He Q. Hypoxia is a potential risk factor for chronic inflammation and adiponectin reduction in adipose tissue of ob/ob and dietary obese mice. Am J Physiol Endocrinol Metab 2007; 293: E1118-28.

5 Larsen OA, Lassen NA, Quaade F. Blood flow through human adipose tissue determined with radioactive xenon. Acta Physiol Scand 1966; 66: 337-45.

6 Crandall DL, Goldstein BM, Huggins F, Cervoni P. Adipocyte blood flow: influence of age, anatomic location, and dietary manipulation. Am J Physiol 1984; 247: R46-51.

7 West DB, Prinz WA, Francendese AA, Greenwood MR. Adipocyte blood flow is decreased in obese Zucker rats. Am J Physiol 1987; 253: R228-33.

8 Brose N, Rosenmund C. Move over protein kinase C, you've got company: alternative cellular effectors of diacylglycerol and phorbol esters. J Cell Sci 2002; 115: 4399-411.

9 Costanzi S, Neumann S, Gershengorn MC. Seven transmembranespanning receptors for free fatty acids as therapeutic targets for diabetes mellitus: pharmacological, phylogenetic, and drug discovery aspects. J Biol Chem 2008; 283: 16269-73.

10 Aldhahi W, Hamdy O. Adipokines, inflammation, and the endothelium in diabetes. Curr Diab Rep 2003; 3: 293-8.

11 Lee JY, Ye J, Gao Z, Youn HS, Lee WH, Zhao L, et al. Reciprocal modulation of Toll-like receptor-4 signaling pathways involving MyD88 and phosphatidylinositol 3-kinase/AKT by saturated and polyunsaturated fatty acids. J Biol Chem 2003; 278: 37041-51.

12 Weigert C, Brodbeck K, Staiger H, Kausch C, Machicao F, Häring $\mathrm{HU}$, et al. Palmitate, but not unsaturated fatty acids, induces the expression of interleukin- 6 in human myotubes through proteasomedependent activation of nuclear factor-kappaB. J Biol Chem 2004; 279: 23942-52. 
Proc Natl Acad Sci U S A 1997; 94: 9660-4.

13 Gao Z, Zhang X, Zuberi A, Hwang D, Quon MJ, Lefevre M, et al. Inhibition of insulin sensitivity by free fatty acids requires activation of multiple serine kinases in 3T3-L1 adipocytes. Mol Endocrinol 2004; 18: 2024-34.

14 Nakamura T, Furuhashi M, Li P, Cao H, Tuncman G, Sonenberg N, et al. Double-stranded RNA-dependent protein kinase links pathogen sensing with stress and metabolic homeostasis. Cell 2010; 140: 338-48.

15 Ozcan U, Cao Q, Yilmaz E, Lee AH, Iwakoshi NN, Ozdelen E, et al. Endoplasmic reticulum stress links obesity, insulin action, and type 2 diabetes. Science 2004; 306: 457-61.

16 Hotamisligil GS, Arner P, Caro JF, Atkinson RL, Spiegelman BM. Increased adipose tissue expression of tumor necrosis factor-alpha in human obesity and insulin resistance. J Clin Invest 1995; 95: 2409-15.

17 Hotamisligil GS, Peraldi P, Budavari A, Ellis R, White MF, Spiegelman BM. IRS-1-mediated inhibition of insulin receptor tyrosine kinase activity in TNF-alpha- and obesity-induced insulin resistance. Science 1996; 271: 665-8.

18 Hotamisligil GS. The role of TNFalpha and TNF receptors in obesity and insulin resistance. J Intern Med 1999; 245: 621-5.

19 Peraldi P, Hotamisligil GS, Buurman WA, White MF, Spiegelman BM. Tumor necrosis factor (TNF)-alpha inhibits insulin signaling through stimulation of the p55 TNF receptor and activation of sphingomyelinase. J Biol Chem 1996; 271: 13018-22.

20 Aguirre V, Uchida T, Yenush L, Davis R, White MF. The c-Jun NH(2)terminal kinase promotes insulin resistance during association with insulin receptor substrate-1 and phosphorylation of Ser(307). J Biol Chem 2000; 275: 9047-54.

21 Chitturi S, Farrell GC. Etiopathogenesis of nonalcoholic steatohepatitis. Semin Liver Dis 2001; 21: 27-41.

22 Gao Z, Hwang D, Bataille F, Lefevre M, York D, Quon MJ, et al. Serine phosphorylation of insulin receptor substrate 1 by inhibitor kappa $B$ kinase complex. J Biol Chem 2002; 277: 48115-21.

23 De Fea K, Roth RA, Modulation of insulin receptor substrate-1 tyrosine phosphorylation and function by mitogen-activated protein kinase. J Biol Chem 1997; 272: 31400-6.

24 Engelman JA, Berg AH, Lewis RY, Lisanti MP, Scherer PE. Tumor necrosis factor alpha-mediated insulin resistance, but not dedifferentiation, is abrogated by MEK1/2 inhibitors in 3T3-L1 adipocytes. Mol Endocrinol 2000; 14: 1557-69.

25 Rui L, Aguirre V, Kim JK, Shulman GI, Lee A, Corbould A, et al. Insulin/IGF-1 and TNF-alpha stimulate phosphorylation of IRS-1 at inhibitory Ser307 via distinct pathways. J Clin Invest 2001; 107 : 181-9.

26 De Fea K, Roth RA. Protein kinase $\mathrm{C}$ modulation of insulin receptor substrate-1 tyrosine phosphorylation requires serine 612. Biochemistry, 1997; 36: 12939-47.

27 Li Y, Soos TJ, Li X, Wu J, Degennaro M, Sun X, et al. Protein kinase C Theta inhibits insulin signaling by phosphorylating IRS1 at Ser(1101). J Biol Chem 2004; 279: 45304-7.

28 Ravichandran LV, Esposito DL, Chen J, Quon MJ. Protein kinase C-zeta phosphorylates insulin receptor substrate-1 and impairs its ability to activate phosphatidylinositol 3-kinase in response to insulin. J Biol Chem 2001; 276: 3543-9.

29 Paz K, Liu YF, Shorer H, Hemi R, LeRoith D, Quan M, et al. Phosphorylation of insulin receptor substrate-1 (IRS-1) by protein kinase $B$ positively regulates IRS-1 function. J Biol Chem 1999; 274: $28816-$ 22.

30 Eldar-Finkelman H, Krebs EG. Phosphorylation of insulin receptor substrate 1 by glycogen synthase kinase 3 impairs insulin action.
31 Ilouz R, Kowalsman N, Eisenstein M, Eldar-Finkelman H. Identification of novel glycogen synthase kinase-3beta substrate-interacting residues suggests a common mechanism for substrate recognition. J Biol Chem 2006; 281: 30621-30.

32 Liberman Z, Eldar-Finkelman H. Serine 332 phosphorylation of insulin receptor substrate-1 by glycogen synthase kinase-3 attenuates insulin signaling. J Biol Chem 2005; 280: 4422-8.

33 Kim JA, Yeh DC, Ver M, Li Y, Carranza A, Conrads TP, et al. Phosphorylation of Ser24 in the pleckstrin homology domain of insulin receptor substrate-1 by Mouse Pelle-like kinase/interleukin-1 receptor-associated kinase: cross-talk between inflammatory signaling and insulin signaling that may contribute to insulin resistance. J Biol Chem 2005; 280: 23173-83.

34 Ozes ON, Akca H, Mayo LD, Gustin JA, Maehama T, Dixon JE, et al. A phosphatidylinositol 3-kinase/Akt/mTOR pathway mediates and PTEN antagonizes tumor necrosis factor inhibition of insulin signaling through insulin receptor substrate-1. Proc Natl Acad Sci U S A 2001; 98: 4640-5.

35 Haruta T, Uno T, Kawahara J, Takano A, Egawa K, Sharma PM, et al. A rapamycin-sensitive pathway down-regulates insulin signaling via phosphorylation and proteasomal degradation of insulin receptor substrate-1. Mol Endocrinol 2000; 14: 783-94.

36 Zhang J, Gao Z, Yin J, Quon MJ, Ye J. S6K directly phosphorylates IRS-1 on Ser-270 to promote insulin resistance in response to TNF(alpha) signaling through IKK2. J Biol Chem 2008; 283: 35375-82.

37 Arkan MC, Hevener AL, Greten FR, Maeda S, Li ZW, Long JM, et al. IKK-beta links inflammation to obesity-induced insulin resistance. Nat Med 2005; 11: 191-8.

38 Karin M, Ben-Neriah Y. Phosphorylation meets ubiquitination: the control of NF-[kappa]B activity. Annu Rev Immunol 2000; 18: 62163.

39 Cummins EP, Berra E, Comerford KM, Ginouves A, Fitzgerald KT, Seeballuck $F$, et al. Prolyl hydroxylase-1 negatively regulates IkappaB kinase-beta, giving insight into hypoxia-induced NFkappaB activity. Proc Natl Acad Sci U S A 2006; 103: 18154-9.

40 Hacker H, Karin M. Regulation and function of IKK and IKK-related kinases. Sci STKE 2006; 2006: re13.

41 Baeuerle PA, Henkel T. Function and activation of NF-kappa B in the immune system. Annu Rev Immunol 1994; 12: 141-79.

42 Schmitz ML, Baeuerle PA. The p65 subunit is responsible for the strong transcription activating potential of NF-kappa B. EMBO J 1991; 10: 3805-17.

43 Bohuslav J, Kravchenko VV, Parry GC, Erlich JH, Gerondakis S, Mackman N, et al. Regulation of an essential innate immune response by the p50 subunit of NF-kappaB. J Clin Invest 1998; 102: $1645-52$.

44 Gao Z, He Q, Peng B, Chiao PJ, Ye J. Regulation of nuclear translocation of HDAC3 by IkappaBalpha is required for tumor necrosis factor inhibition of peroxisome proliferator-activated receptor gamma function. J Biol Chem 2006; 281: 4540-7.

45 Boden G. Free fatty acids (FFA), a link between obesity and insulin resistance. Front Biosci 1998; 3: d169-75.

46 Ferrannini E, Barrett EJ, Bevilacqua S, DeFronzo RA. Effect of fatty acids on glucose production and utilization in man. J Clin Invest 1983; 72: 1737-47.

47 Griffin ME, Marcucci MJ, Cline GW, Bell K, Barucci N, Lee D, et al. Free fatty acid-induced insulin resistance is associated with activation of protein kinase $\mathrm{C}$ theta and alterations in the insulin signaling cascade. Diabetes 1999; 48: 1270-4.

48 Schmitz-Peiffer C, Oakes ND, Browne CL, Kraegen EW, Biden TJ. 
Reversal of chronic alterations of skeletal muscle protein kinase C from fat-fed rats by BRL-49653. Am J Physiol 1997; 273: E915-21.

49 Delarue J, Magnan C. Free fatty acids and insulin resistance. Curr Opin Clin Nutr Metab Care 2007; 10: 142-8.

50 Thompson AL, Cooney GJ. Acyl-CoA inhibition of hexokinase in rat and human skeletal muscle is a potential mechanism of lipid-induced insulin resistance. Diabetes 2000; 49: 1761-5.

51 Utaka S, Avesani CM, Draibe SA, Kamimura MA, Andreoni S, Cuppari L. Inflammation is associated with increased energy expenditure in patients with chronic kidney disease. Am J Clin Nutr 2005; 82: 801-5.

52 Moldawer LL, Georgieff M, Lundholm K. Interleukin 1, tumour necrosis factor-alpha (cachectin) and the pathogenesis of cancer cachexia. Clin Physiol 1987; 7: 263-74.

53 Barot LR, Rombeau JL, Steinberg JJ, Crosby LO, Feurer ID, Mullen $\mathrm{JL}$. Energy expenditure in patients with inflammatory bowel disease. Arch Surg 1981; 116: 460-2.

54 Chan AT, Fleming CR, O'Fallon WM, Huizenga KA. Estimated versus measured basal energy requirements in patients with Crohn's disease. Gastroenterology 1986; 91: 75-8.

55 Strasser F. Appraisal of current and experimental approaches to the treatment of cachexia. Curr Opin Support Palliat Care 2007; 1: 312-6.

56 Tisdale MJ. Biology of cachexia. J Natl Cancer Inst 1997; 89: 176373.

57 Tang T, Zhang J, Yin J, Staszkiewicz J, Gawronska-Kozak B, Jung DY, et al. Uncoupling of inflammation and insulin resistance by NF-kappaB in transgenic mice through elevated energy expenditure. J Biol Chem 2010; 285: 4637-44.

58 Gao Z, Yin J, Zhang J, He Q, McGuinness OP, Ye J. Inactivation of NFkappaB p50 leads to insulin sensitization in liver through post-translational inhibition of p70S6K. J Biol Chem 2009; 284: 18368-76.

59 Pamir N, McMillen TS, Kaiyala KJ, Schwartz MW, LeBoeuf RC. Receptors for tumor necrosis factor-alpha play a protective role against obesity and alter adipose tissue macrophage status. Endocrinology 2009; 150: 4124-34.

60 Chida D, Osaka T, Hashimoto O, Iwakura Y. Combined interleukin-6 and interleukin-1 deficiency causes obesity in young mice. Diabetes 2006; 55: 971-7.

61 Wallenius V, Wallenius K, Ahrén B, Rudling M, Carlsten H, Dickson SL, et al. Interleukin-6-deficient mice develop mature-onset obesity. Nat Med 2002; 8: 75-9.

62 Ye J, Keller JN. Regulation of energy metabolism by inflammation: a feedback response in obesity and calorie restriction. Aging (Albany NY) 2010; 2: 361-8.

63 Kopp E, Ghosh S. Inhibition of NF-kappa B by sodium salicylate and aspirin. Science 1994; 265: 956-9.

64 Pierce JW, Read MA, Ding H, Luscinskas FW, Collins T. Salicylates inhibit I kappa B-alpha phosphorylation, endothelial-leukocyte adhesion molecule expression, and neutrophil transmigration. J Immunol 1996; 156: 3961-9.

65 Shoelson SE, Lee J, Goldfine AB. Inflammation and insulin resistance. J Clin Invest 2006; 116: 1793-801.

66 Williamson RT. On the treatment of glycosuria and diabetes mellitus with sodium salicylate. Br Med J 1901; 1: 760-2.

67 Yin MJ, Yamamoto Y, Gaynor RB. The anti-inflammatory agents aspirin and salicylate inhibit the activity of I(kappa)B kinase-beta. Nature 1998; 396: 77-80.

68 Gao Z, Zuberi A, Quon MJ, Dong Z, Ye J. Aspirin inhibits serine phosphorylation of insulin receptor substrate 1 in tumor necrosis factor-treated cells through targeting multiple serine kinases. J Biol
Chem 2003; 278: 24944-50.

69 Dichtl W, Dulak J, Frick M, Alber HF, Schwarzacher SP, Ares MP, et al. HMG-CoA reductase inhibitors regulate inflammatory transcription factors in human endothelial and vascular smooth muscle cells. Arterioscler Thromb Vasc Biol 2003; 23: 58-63.

70 Chan DC, Watts GF, Barrett PH, Beilin LJ, Mori TA. Effect of atorvastatin and fish oil on plasma high-sensitivity C-reactive protein concentrations in individuals with visceral obesity. Clin Chem 2002; 48: 877-83.

71 Preiss D, Seshasai SR, Welsh P, Murphy SA, Ho JE, Waters DD, et al. Risk of incident diabetes with intensive-dose compared with moderate-dose statin therapy. JAMA 2011; 305: 2556-64.

72 Burén J, Liu HX, Jensen J, Eriksson JW. Dexamethasone impairs insulin signalling and glucose transport by depletion of insulin receptor substrate-1, phosphatidylinositol 3-kinase and protein kinase B in primary cultured rat adipocytes. Eur J Endocrinol 2002; 146: 419-29.

73 Perry CG, Spiers A, Cleland SJ, Lowe GD, Petrie JR, Connell JM. Glucocorticoids and insulin sensitivity: dissociation of insulin's metabolic and vascular actions. J Clin Endocrinol Metab 2003; 88: 6008-14.

74 Böni-Schnetzler M, Thorne J, Parnaud G, Marselli L, Ehses JA, KerrConte J, et al. Increased interleukin (IL)-1beta messenger ribonucleic acid expression in beta-cells of individuals with type 2 diabetes and regulation of IL-1beta in human islets by glucose and autostimulation. J Clin Endocrinol Metab 2008; 93: 4065-74.

75 Dinarello CA. Biologic basis for interleukin-1 in disease. Blood 1996; 87: 2095-147.

76 Maedler K, Sergeev P, Ris F, Oberholzer J, Joller-Jemelka HI, Spinas GA, et al. Glucose-induced beta cell production of IL-1beta contributes to glucotoxicity in human pancreatic islets. J Clin Invest 2002; 110: 851-60.

77 Ventre J, Doebber T, Wu M, MacNaul K, Stevens K, Pasparakis M,, et al. Targeted disruption of the tumor necrosis factor-alpha gene: metabolic consequences in obese and nonobese mice. Diabetes 1997; 46: 1526-31.

78 Schreyer SA, Chua Jr SC, LeBoeuf RC. Obesity and diabetes in TNFalpha receptor-deficient mice. J Clin Invest 1998; 102: 402-11.

79 Dominguez H, Storgaard H, Rask-Madsen C, Steffen Hermann T, Ihlemann N, Baunbjerg Nielsen D, et al. Metabolic and vascular effects of tumor necrosis factor-alpha blockade with etanercept in obese patients with type 2 diabetes. J Vasc Res 2005; 42: 517-25.

80 Lo J, Bernstein LE, Canavan B, Torriani M, Jackson MB, Ahima RS, et al. Effects of TNF-alpha neutralization on adipocytokines and skeletal muscle adiposity in the metabolic syndrome. Am J Physiol Endocrinol Metab 2007; 293: E102-9.

81 Ofei F, Hurel S, Newkirk J, Sopwith M, Taylor R. Effects of an engineered human anti-TNF-alpha antibody (CDP571) on insulin sensitivity and glycemic control in patients with NIDDM. Diabetes 1996; 45: 881-5.

82 Paquot N, Castillo MJ, Lefèbvre PJ, Scheen AJ. No increased insulin sensitivity after a single intravenous administration of a recombinant human tumor necrosis factor receptor: Fc fusion protein in obese insulin-resistant patients. J Clin Endocrinol Metab 2000; 85: 13169.

83 Rosenvinge A, Krogh-Madsen R, Baslund B, Pedersen BK. Insulin resistance in patients with rheumatoid arthritis: effect of antiTNFalpha therapy. Scand J Rheumatol 2007; 36: 91-6.

84 Matthews VB, Allen TL, Risis S, Chan MH, Henstridge DC, Watson N, et al. Interleukin-6-deficient mice develop hepatic inflammation and systemic insulin resistance. Diabetologia 2010; 53: 2431-41. 
Histone deacetylase inhibition attenuates diabetes-associated kidney growth: potential role for epigenetic modification of the epidermal growth factor receptor. Kidney Int 2011; 79: 1312-21.

97 Christensen DP, Dahllöf M, Lundh M, Rasmussen DN, Nielsen MD, Billestrup N, et al. Histone deacetylase (HDAC) inhibition as a novel treatment for diabetes mellitus. Mol Med 2011; 17: 378-390.

98 Gao Z, Yin J, Zhang J, Ward RE, Martin RJ, Lefevre M, et al. Butyrate improves insulin sensitivity and increases energy expenditure in mice. Diabetes 2009; 58: 1509-17.

99 Fajas L, Egler V, Reiter R, Hansen J, Kristiansen K, Debril MB, et al. The retinoblastoma-histone deacetylase 3 complex inhibits PPARgamma and adipocyte differentiation. Dev Cell 2002; 3: 90310.

100 Guan HP, Ishizuka T, Chui PC, Lehrke M, Lazar MA. Corepressors selectively control the transcriptional activity of PPARgamma in adipocytes. Genes Dev 2005; 19: 453-61.

101 Miard S, Fajas L. Atypical transcriptional regulators and cofactors of PPARgamma. Int J Obes (Lond) 2005; 29: S10-2.

102 Zhang J, Henagan TM, Gao Z, Ye J. Inhibition of glyceroneogenesis by histone deacetylase 3 contributes to lipodystrophy in mice with adipose tissue inflammation. Endocrinology 2011; 152: 1829-38.

103 Rahman I. Oxidative stress, transcription factors and chromatin remodelling in lung inflammation. Biochem Pharmacol 2002; 64: 935-42.

104 Adcock IM, Ito K, Barnes PJ. Histone deacetylation: an important mechanism in inflammatory lung diseases. COPD 2005; 2: 445-55.

105 Blanchard F, Chipoy C. Histone deacetylase inhibitors: new drugs for the treatment of inflammatory diseases? Drug Discov Today 2005; 10: $197-204$

106 Dinarello CA. Inhibitors of histone deacetylases as anti-inflammatory drugs. Ernst Schering Res Found Workshop 2006; 56: 45-60.

107 Zhang L, Fang H, Xu W. Strategies in developing promising histone deacetylase inhibitors. Med Res Rev 2010; 30: 585-602.

108 Shakespear MR, Halili MA, Irvine KM, Fairlie DP, Sweet MJ. Histone deacetylases as regulators of inflammation and immunity. Trends Immunol 2011; 32: 335-43.

109 McGee SL, Hargreaves M. Histone modifications and exercise adaptations. J Appl Physiol 2011; 110: 258-63. 